\title{
In Defiance of the Reception Logic: The Case for Including NGOs as Human Rights Monitors in the EU's Policies of First Reception of Irregular Migrants
}

\begin{abstract}
The first reception system for irregular migrants taking the Mediterranean route into the European Union (EU) is dictated almost solely by border control and security concerns. There is no recognition of the role of nongovernmental organizations (NGOs) as human rights monitors in first reception, and access is limited, controlled, and dependent on local authorities. Newly arriving migrants are at their most vulnerable during first reception. Traumatization and retraumatization brought by violations of human rights, or alternatively, care and welcome within the first reception system will pave the way for subsequent integration processes, by ensuring migrants' well-being, decreasing hostility, diffidence and subjugation, and peaceful relations with European host communities. By critically assessing the current system, backed by the author's long-term ethnographic fieldwork, this article explores the links between policy, practice, and mental health consequences for migrants. It shows that there are multiple risks of human rights violations of a vulnerable group of people. The article is critical of the absence of an official role for $\mathrm{NGOs}^{1}$ as human rights monitors arguing that NGOs have a unique role to play. The article suggests that the dignified conduction of first reception could have a positive influence on integration processes, and concludes that first reception should not be designed within a security framework but within a reception one.
\end{abstract}

Public Significance Statement

This article explores the social and political factors of irregular border crossing into the EU.

Keywords: refugees, European Union, first reception, human rights, NGOs

The first reception system for irregularly entering immigrants, including asylum seekers, into the EU is framed almost exclusively by border control and security concerns. This is particularly problematic since it is one of the routes that asylum seekers use to enter the EU. EU law does not provide for the

Editor's Note. Continue the conversation by submitting your comments and questions about this article/book review to PeacePsychology.org/ peaceconflict. (The Editor of PeacePsychology.org reserves the right to exclude material that fails to contribute to constructive discussion.)

Daniela DeBono, received her $\mathrm{PhD}$ degree from the University of Sussex. She is a Senior Lecturer in the Department for Global Political Studies, Malmö University, and currently is Marie Curie COFAS Fellow, Robert Schuman Centre for Advanced Studies, at the European University Institute. Her research interests include forced migration, the migration and human rights nexus, border studies, socio-legal and political anthropology.

THIS ARTICLE draws on a research project carried out during a Marie Curie COFAS Fellowship, which is cofunded by the Swedish Council for Health, Working Life and Welfare (Forte) and the European Commission.

CORRESPONDENCE CONCERNING THIS ARTICLE should be addressed to Daniela DeBono, Marie Curie COFAS Fellow, Robert Schuman Centre for Advanced Studies, European University Institute, Via della Badia dei Roccettini, 9, 50014 Fiesole (FI), Italy. E-mail: daniela.debono@mah.se regulated arrival of asylum seekers and with the progressive selective tightening of its visa regime, there remain few alternatives for people wishing to seek asylum in the EU. Although there are other irregular entry channels, this paper will deal only with irregular border crossings in the EU where migrants are met with the institutional set-up of first reception. Irregular in this article is therefore used to indicate that there is a law-breaking component, such as travel without the necessary documentation and/or the use of unauthorized border-crossing points. Empirically it denotes migrant flows that are not predictable in numbers and composition. The tightening of border regulations and visa regimes of the EU over the years, have made it increasingly more difficult for people from particular countries to gain access into EU countries. This thwarted situation is a result of what Düvell eloquently argues is the "construction of irregular migration by EU laws and policies" (Düvell, 2011, p. 295). Similarly, the EU's border regime has been described as constituting 'global apartheid' (Van Houtum, 2010),

\footnotetext{
${ }^{1}$ An NGO, minimally defined by the United Nations as "a non-forprofit, voluntary citizens' group, which is organized on a local, national or international level to address issues in support of the public good," is not to be confused with intergovernmental organizations. Both types of organizations can play the role of human rights monitors but this article is only concerned with NGOs.
} 
as indulging in 'border imperialism' (Euskirchen, Lebuhn \& Ray, 2007) and which produces 'bare life' (Buckel \& Wissel, 2010).

During the 2015-2016 so-called "refugee/migration crisis," when numbers of irregular migrants crossing the Mediterranean Sea shot up there were two main routes-the Eastern Mediterranean Maritime Route and the Central Mediterranean Maritime Route. On the former, the arrivals in Greece were drastically reduced with the enactment of the EU-Turkey agreement in March, 2016-United Nations High Commissioner for Refugees (UNHCR) statistics designate 816,752 in 2015, 173,150 in 2016, and much less forecast for 2017. In contrast on the Central Route, with departures generally from Libya and arrivals in Italy (or Malta), statistics mark a gradual increase-UNHCR data shows 153,850 in $2015,181,436$ in 2016 and an increase is forecast for 2017. Officially termed mixed migrant flows, the vast majority apply for asylum.

\section{The EU's Common European Asylum System}

AQ: 4 Border control and asylum are the prerogatives of each member state. However the external borders of the EU take on special significance because it is an area of open borders and freedom of movement as dictated by the Schengen Agreement. This can create complicated situations, such as, the phenomenon of "asylum shopping" through which a rejected asylum seeker would submit an application in another EU state, thereby retaining the right to remain in the country/EU. This was partly addressed with the Dublin System, but more comprehensively with the Common European Asylum System (CEAS), which is a harmonization of the EU's asylum policies to guarantee protection for refugees and address abuse. Today the CEAS consists of EU laws (directives), policies, and institutions applicable to all member states. Member states on the EU borders are tasked with the dual responsibility of processing people for irregular entry, the handling of their asylum claims, and/or their return.

\section{The Hotspot Approach}

During the refugee/migration crisis, a hybrid EU-member states ${ }^{2}$ policy tool-the "hotspot approach"-was implemented to provide comprehensive and targeted support to frontline border EU member states during crises (European Commission, 2015). The aim was to augment the effects of assistance by combining information, operational support and capacity building activities from different EU agencies (European Parliament, 2016). It was presented as part of a response to southern-EU member states who asked for greater intra-EU solidarity to deal with irregular migration. The general framework of procedural policies developed through the enactment of the hotspot approach, which deals with identification, registration, and fingerprinting, is the prototype of first reception of irregularly entering migrants.

From a human rights point of view this is a source of concern. The hotspot approach, constructed as it is within a securitized framework and entrenched within a continuous emergency culture, carries significant classic risks of human rights violations that have to do with interrogations, use of force, arbitrary detention, and maintenance of public order. In addition, reporting by migrants themselves, in particular those who intend to apply for asylum, is generally limited for fear of prejudicing their asylum application or being returned. Also present are broader human rights concerns dealing with preemptive action to ensure that sociocultural rights and respectful treatment of the person are safeguarded. A jointNGO report on the hotspots in Italy and Greece shows how the hotspot approach has led to "more repressive measures, often disrespecting fundamental rights, which are applied by national authorities as a result of EU pressure to control the arrivals" (European Council on Refugees and Exiles, 2016, p. 7). In addition to all this, what adds to the gravity is the knowledge that many of these new arrivals are vulnerable for various reasons: they have less capacity to challenge inhumane situations; and from a mental health point of view, inhumane treatment would constitute not just traumatization but rather retraumatization.

The "refugee/migration crisis" has been used to give an impetus to the reinforcement of the external border of the EU and to test various models, among which is that of first reception. Unfortunately, the greater the EU's intensification of its migration and border policy, the greater the pressure of irregular migrant flows. It is therefore likely that there will always be points which, however tightly controlled and militarized they may be, either give way under pressure, or are intentionally loosened as a safety valve. In either case, this opens the opportunity to the authorities to approach these nodes as humanitarian situations. Again this does not augur well from a human rights point of view. The logic of using humanitarianism as a pretext for repression in this field is not new: Fassin (2005) describes how the Sangatte Center in France was governed by compassion and repression reflecting the shift in language from human rights to charity. Khosravi (2009) describes how the Swedish deportation system uses the language of humanitarianism in order to better control migrants. Mainwaring (2012) shows how the constructing of a crisis scenario in Malta enabled the authorities to approach it as an exceptional situation, which in turn justified the 18-month detention of asylum-seekers in "less than human" conditions (DeBono, 2013).

To sum up, first reception is built on the principles of security coming from the border control regime, and humanitarianism coming from the crisis/emergency narrative. Research shows that they are equally used as part of an orchestrated drive by the EU for more efficient bordering. The resulting repression of migrants and the elevated risks of human rights violations make the case for independent human rights monitoring, including that by NGOs. Unfortunately, apart from a cursory role of UNHCR to "assist in the implementation, in line with current practice (identification, submission, transfer, etc.)" (European Commission, 2015, p. 20) in the official documents that designate the hotspot approach (European Commission, 2015; European Parliament, 2016), there is no mention of human rights or of the role of NGOs in conducting human rights monitoring.

\footnotetext{
${ }^{2}$ The hotspot approach is activated by member states during periods of unmanageable flows and run by teams made up of officials from the European Asylum Support Office, the EU Border Agency, the EU Police Cooperation Agency, and the EU Judicial Cooperation Agency. Currently it is operational in Greece and Italy.
} 


\section{Vulnerabilities: Preexisting and Provoked by the EU System}

Identification and specific processing of vulnerable migrants, such as children, disabled, or people who have endured violence, give the wrong impression that all the rest are strong and powerful. In fact, migrants who make the Mediterranean crossing often arrive physically and psychologically weak. This is not recognized by the authorities, and migrants can be rendered even more vulnerable by the first and secondary reception systems, which is manifested by a downward spiral of their personal or mental health. There are multiple reasons for this tied either to the original motivation to leave their country of origin or transit countries, or as a result of experiences during or the journey. Trovato et al. (2016) draw on the high rate of morbidity of the Mediterranean crossing-IOM reports 5,141 recorded deaths out of a worldwide total of 7,888 in 2016 (IOM, 2017) — to show that this suggests the journey affected migrants' health. Furthermore, signaling the current inadequacy, the study recommends that the EU's response to the crisis should include the provision of initial medical care in order to meet its humanitarian obligations and support local medical facilities (Trovato et al., 2016). Another factor is certainly Libya, the last country of transit before the central Mediterranean crossing, known to be a particularly dangerous place for migrants and refugees, where irregularity is criminalized and basic rights are violated. Postconflict, the situation has degenerated further as can be seen in a report by UNSML and OHCHR (2016), which details the "'unimaginable' human rights violations and abuses of migrants in Libya as a result of the breakdown in the crisis-riven country's justice system" (UN News Centre, 2016).

The incidence of mental illness among asylum seekers exposed to traumatic events is high, and there is a general deterioration of mental health in prolonged stays in reception centers. A Médecins Sans Frontières (MSF) study aptly called Neglected Traumas shows that an extremely high percentage $-86.9 \%$ - of the patients seen by MSF said they had difficulties in postmigration life and this distress was associated with a diagnosis of PTSD and anxiety disorders. The most common difficulties in life acquired in postmigration period are: the feeling of uncertainty and fear for the future, concern for the family back home, conflicts within the migrants' center (Centro di Accoglienza Straordinaria [CAS]), fear of the asylum request being rejected, the feeling of being neglected, the inability to integrate and feel integrated, prolonged waiting times for the Commission's outcomes, lack of daily activities, a sense of loneliness and boredom, and, to a lesser extent, other difficulties such a widespread sense of injustice and feeling unable to control events. In addition to this list, the report notes that patients complained of a variety of difficulties in postmigration life, and that traumatic events suffered during the migratory journey also contributed to PTSD disorders and depression. (Médecins Sans Frontières, 2016, p. 27)

The MSF study echoes findings of previous studies held in different continents. On the Australian asylum system Silove, Sinnerbrink, Field, Manicavasagar, and Steel (1997) conclude that procedures dealing with asylum seekers "contribute to high levels of stress and psychiatric symptoms in those who have been previously traumatized" (p. 351). On the topic of mental health care in humanitarian situations, a special issue of the Bulletin of the World Health Organization brings together a group of papers that discuss how in humanitarian situations when health care systems are overwhelmed mental health care is often overlooked (Ventevogel, Van Ommeren, Schilperoord, \& Saxena, 2015).

Moreover, the first reception system enlists detention for the purposes of identification. This imposition of detention during the initial stay, such as in the Reception and Identification Centres (RIC) in Greece, is a "de facto deprivation of liberty" (AIDA, 2017 , p. 2), bringing with it the ensuing legal complications and psychological impact of the violation of this human right. In itself, detention makes a person vulnerable even in the absence of preexisting vulnerabilities. This was demonstrated by a pan-European study (JRS Europe, 2010) that explored how preexisting vulnerable groups cope with detention, and the way in which detention can enable vulnerability in persons who do not otherwise possess officially recognized vulnerabilities and special needs. The study highlighted that from the first day of their detention, the individual's personal wellbeing nosedives due to their "disadvantaged and weakened position" (JRS Europe, 2010, p. 12). Expressively, the study states:

The prison-like environments existing in many detention centers, the isolation from the "outside world," the unreliable flow of information and the disruption of a life plan lead to mental health impacts such as depression, self-uncertainty, and psychological stress, as well as physical health impacts such as decreased appetite and varying degrees of insomnia. (JRS Europe, 2010, p. 13)

Similarly, Robjant, Hassan, and Katona (2009) through a systematic review of studies investigating the impact of immigration detention on the mental health of children, adolescents, and adults, conclude that detention has an independent and adverse effect on mental health. And DeBono (2013) and Hartley and Fleay (2017), through evocative quotes from migrants themselves, show how migrants in Malta and in Australia respectively experience detention as inhumane, denouncing detention as a human rights violation.

\section{Independent Human Rights Monitors-the Role of NGOs}

After showing how the hotspot model "carried important risks from a human rights perspective" (ECRE, 2016, p. 9), an ECRE report highlights the importance of safeguards and rigorous human rights monitoring. Claims for the need of effective human rights protection and monitoring at international borders are not new. The United Nations Office of the High Commissioner for Human Rights (OHCHR) had outlined the potential risks that activity at international borders entails for the safeguarding of human rights of migrants and recommended independent human rights monitoring, including by civil society:

Encouraging independent monitoring of human rights at international borders and establishing or strengthening systematic reporting mechanisms, including through facilitating cooperation between border authorities and other actors including police, national human rights institutions, parliamentarians, civil society, and international organizations. Supporting all relevant actors to bring complaints in the event of violations of human rights at borders. (OHCHR, 2014, p. 15)

Indeed, the role of NGOs and civil society in independent human rights monitoring is crucial and its function is distinct to 
that by intergovernmental bodies or other institutions. Their role as "constructive power building vibrant democracy and peopleoriented development" is recognized, as is their absence considered "a criterion for an authoritarian move" (Dar, 2015, p. 1). The Council of Europe, a leading human rights organization (not to be confused with the EU), lists the specific contribution of civil society as:

- fighting individual violations of human rights either directly or by supporting particular "test cases" through relevant courts

- offering direct assistance to those whose rights have been violated

- lobbying for changes to national, regional, or international law

- helping to develop the substance of those laws

- promoting knowledge of, and respect for, human rights among the population (Council of Europe, 2017).

In order to achieve the above, NGO presence needs to be facilitated. Currently, publications of human rights reports by NGOs are occasional and often based on a series of meetings with the authorities and service providers. Access, and the quality of it, depends on the national and local authorities. As a result of this limited access, some local and international NGOs enter into service agreements with the authorities in various parts of the first reception process. This allows them to monitor and to identify human rights violations in their area of operation, but this situation does not allow them to share information on human rights violations in a manner that could pressure the authorities to enact changes. Since access and the provision of their service is dependent on a trust relationship with the authorities, they rarely rock the boat. A notable exception is MSF, which withdrew its medical services from reception centers in Malta and Sicily in order to draw the attention to human rights. MSF claimed that they were treating illnesses that were brought about by detention and the conditions within the center-controversially leaving migrants without an adequate service. Such situations would be avoided if NGOs were guaranteed an operative space as human rights monitors.

Access should be based on four premises. First, the elevated risks of human rights violations in first reception. Second, a recognition of NGOs and civil society as important parts of the human rights system. Third, citizens' involvement in the first reception system can create a better culture of hospitality and concurrently, increase awareness about the functioning of the border. Fourth, removing the mysticism of border procedures among citizens can help in allaying "othering" fears, which feed populist politics making it difficult to engage in integration practices.

\section{The Need for the Enactment of a Safe Space Devoid of Risks of Human Rights Violations}

This lack of access and human rights monitoring by NGOs within the securitized areas of first reception for irregularly arriving maritime migrants into the EU, is a major concern. The majority of migrant arrivals submit official requests for asylum, and therefore have a right to reception and subsequently integration programs. A failure to safeguard their human rights at the border during first reception could have mental health consequences for migrants, and will likely have a negative impact on integration processes. The current system, with the implementation of the hotspot approach, does not envisage a space for NGOs either as independent monitors or as accompaniment and support to migrants. Currently NGOs' access (if any at all) to the wharf, the hotspot, and any other first reception centers are contingent on the goodwill of local or national authorities.

As long as the first reception process remains dictated by the exigencies of border control and security concerns, for processes like identification, intelligence collecting, and registration, it will be difficult to safeguard the human rights of migrants. The imposition of detention in the hotspots is there to ensure that these activities are carried out, often directly or indirectly removing the option for the migrant to refuse. One needs to question, for example, whether in the current scenario when migrants arrive vulnerable and generally apply for asylum, how reasonable it is to effect identification, interrogations and registration immediately upon arrival. A more sensible and humane option would be to give some time to migrants to rest, recuperate, and therefore be in a state of mind to understand the processes that they are going through? Depriving arbitrarily vulnerable people of their liberty and treating them as criminals when, in the case of asylum seekers, border crossing for the purposes of asylum seeking is not an offense. Integration, understood loosely to be a social two-way process of encounter and adaption (albeit problematically hiding power imbalances $^{3}$ ), can be hampered by the lack of respectful treat- Fn3 ment at first reception. Whereas NGO involvement and access not only encourages positive encounters but by demystifying the border procedures, addresses also an "othering" process that only hinders integration.

First reception needs to become a safe space devoid of the potential for human rights violations and inhumane treatment where migrants can connect with trusted individuals, recollect themselves and seek help when needed. NGOs have a key role to play in the construction of this, and in keeping check on the authorities to retain this balance. It is only when first reception starts taking the characteristics of reception that it be justifiably claimed that the mainstreaming of human rights at the border is being taken seriously.

\footnotetext{
${ }^{3}$ It is unfortunate that this paper did not permit a critical discussion of the notion of integration. Integration is understood within the frame of social justice, and use of the term in this paper is often accompanied by social justice. Integration is widely used by policymakers and in academic literature; however, it is not a neutral concept and is underpinned by unnecessary essentialisms which run counter to the notion of integration itself. Two of these are: (a) the problematic idea that identity is fixed without challenges and negotiations; and b) the exclusion of consideration of power and structural factors brought about by a focus on integration as exclusively cultural. For more on this see Anthias, 2013 who proposes a translocational approach, which "is not focused on cultural difference but on inequalities and subordinations that are produced intersectionally; it therefore moves beyond culture and ethnicity, and considers material struggles over resources of different types. It refuses to locate identities, therefore, purely in terms of one parameter of difference and identity, asking us to also consider class and gender processes where relevant (and those of other social categories and divisions such as sexuality, age and disability, for example)" (pp. 337-338).
}

\section{References}

AIDA. (2017). The detention of asylum seekers in Europe Constructed on shaky ground? Brussels, Belgium: European Council of Refugees and Exiles. 
Anthias, F. (2013). Moving beyond the Janus face of integration and diversity discourses: Towards an intersectional framing. The Sociological Review, 61, 323-343.

Buckel, S., \& Wissel, J. (2010). State Project Europe: The transformation of the European border regime and the production of bare life. International Political Sociology, 4, 33-49. http://dx.doi.org/10.1111/j.1749-

AQ: $10 \quad 5687.2009 .00089 . x$

Council of Europe. (2017). Human rights activism and the role of NGOs. Retrieved from http://www.coe.int/en/web/compass/human-rightsactivism-and-the-role-of-ngos

Dar, F. (2015). Emerging role of NGOs in the world's socio-political affairs. International Journal of Peace and Development Studies, 6, 1-9.

DeBono, D. (2013). 'Less than human': The detention of irregular immigrants in Malta. Race \& Class, 55, 60-81. http://dx.doi.org/10.1177/ 0306396813497880

Düvell, F. (2011). Paths into irregularity: The legal and political construction of irregular migration. European Journal of Migration and Law, 13, 275-295. http://dx.doi.org/10.1163/157181611X587856

European Commission. (2015). Communication from the Commission to the European Parliament, the Council, the European Economic and Social Committee and the Committee of the Regions: A European agenda on migration. Brussels, Belgium: ESSC. Retrieved from http:// www.eesc.europa.eu/en/our-work/opinions-information-reports/opinions/ european-agenda-migration-communication

European Council on Refugees and Exiles (ECRE). (2016). The implementation of the hotspots in Italy and Greece-A study. Retrieved from https://www.ecre.org/wp-content/uploads/2016/12/HOTSPOTS-Report5.12.2016.pdf

European Parliament. (2016). On the frontline: The hotspot approach to managing migration. Brussels, Belgium: European Parliament Policy Department for Citizen's Rights and Constitutional Affairs.

Euskirchen, M. Lebuhn, H. \& Ray, G. (2007). From borderline to border-

AQ: 11 land: The changing European border. Monthly Review, 59, 42-53.

Fassin, D. (2005). Compassion and repression: The moral economy of immigration policies in France. Cultural Anthropology, 20, 362-387. http://dx.doi.org/10.1525/can.2005.20.3.362

Hartley, L., \& Fleay, C. (2017). "We are like animals": Negotiating dehumanizing experiences of asylum seeker policies in the Australian community. Refugee Survey Quarterly, 36, 1-19.

International Organisation of Migration (IOM). (2017). Migrants: Tracking deaths along migratory routes. Retreived from https://missingmig rants.iom.int/
JRS Europe. (2010). Becoming vulnerable in detention: Civil society report on the detention of vulnerable asylum seekers and irregular migrants in the European Union. Brussels, Belgium: JRS Europe.

Khosravi, S. (2009). Sweden: Detention and deportation of asylum seekers. Race \& Class, 50, 38-56. http://dx.doi.org/10.1177/0306396809102996

Mainwaring, C. (2012). Constructing a crisis: The role of immigration detention in Malta. Population Space and Place, 18, 687-700. http://dx .doi.org/10.1002/psp.1721

Médecins Sans Frontières-Belgium. (2016). Neglected trauma, asylum seekers in Italy: An analysis of mental health distress and access to healthcare. Brussels, Belgium: Author.

Office of the High Commissioner for Human Rights (OHCHR). (2014). Recommended principles and guidelines on human rights at international borders. Geneva, Switzerland: United Nations.

Robjant, K., Hassan, R., \& Katona, C. (2009). Mental health implications of detaining asylum seekers: Systematic review. The British Journal of Psychiatry, 194, 306-312. http://dx.doi.org/10.1192/bjp.bp.108.053223

Silove, D., Sinnerbrink, I., Field, A., Manicavasagar, V., \& Steel, Z. (1997). Anxiety, depression and PTSD in asylum-seekers: Associations with pre-migration trauma and post-migration stressors. The British Journal of Psychiatry, 170, 351-357. http://dx.doi.org/10.1192/bjp.170 .4 .351

Trovato, A., Reid, A., Takarinda, K. C., Montaldo, C., Decroo, T., Owiti, P.,Bongiorno, F , Di Carlo,S.(2016).Dangerous crossing: Demographic and clinical features of rescued sea migrants seen in 2014 at an outpatient clinic at Augusta Harbor, Italy. Conflict and

Unftedlt Xations-Support Mission in Libya (UNSML) and Office of the United Nations High Commissioner for Human Rights (OHCHR). (2016). "Detained and dehumanized": Report on human rights abuses against migrants in Libya. Retrieved from http://www.ohchr.org/Docu ments/Countries/LY/DetainedAndDehumanised_en.pdf

UN News Centre. (2016). UN human rights report urges end to 'unimaginable abuse' of migrants in Libya. Retrieved from http://www.un.org/ apps/news/story.asp?NewsID=55793\#.WX44eISGPDc

van Houtum, H. (2010). Human blacklisting: The global apartheid of the EU's external border regime. Environment and Planning D, Society \& Space, 28, 957-976. http://dx.doi.org/10.1068/d1909

Ventevogel, P., Van Ommeren, M., Schilperoord, M., \& Saxena, S. (2015). Improving mental health care in humanitarian emergencies. Bulletin of the World Health Organization, 93, 666. http://dx.doi.org/10.2471/BLT .15 .156919 


\section{AUTHOR QUERIES}

\section{AUTHOR PLEASE ANSWER ALL QUERIES}

AQau-Please confirm the given-names and surnames are identified properly by the colors. = Given-Name, $\boldsymbol{a}=$ Surname The colors are for proofing purposes only. The colors will not appear online or in print.

AQ1-Author: Please confirm that running header is acceptable or provide alternate header of 50 characters max. including spaces

AQ2-Author: Please check if correct as edited: “Traumatization and retraumatization brought by violations of human rights, or alternatively, care and welcome..."

AQ3-Author: Please check if Public Significance Statement is complete or is additional text is needed.

AQ4-Author: Please check if header is correct as edited; since "The Hotspot Approach" is discussed in the next section, have removed it from this header ... and spelled out CEAS.

AQ10-Author: (Buckel \& Wissel, 2010) is not cited in the text. Please cite in the text or delete from the references.

AQ11-Author: (Euskirchen, Lebuhn, \& Ray, 2007) is not cited in the text. Please cite in the text or delete from the references.

AQ13-Author: (van Houtum, 2010) is not cited in the text. Please cite in the text or delete from the references.

AQ14-Author: This journal requires each author to provide a brief professional biographical paragraph to include: (a) author's name, (b) highest degree, (c) department and affiliation, (d) current affiliation, (e) area(s) of research interest. If you have not already done so, please provide this information with your proof corrections. 